\title{
Evaluation of Lipid Modified Lipase for Interesterification and Hydrolysis Reactions in $n$-Hexane
}

\author{
Kenneth D. Green, ${ }^{1}$ Mitsutoshi NAKaJima, ${ }^{1, *}$ Sosaku ICHIKAWA ${ }^{1, * *}$ and Kenichi MoGl ${ }^{2}$ \\ ${ }^{1}$ Reaction and Separation Engineering Laboratory, National Food Research Institute, Kannondai 2-1-2, Tsukuba, Ibaraki 305, Japan \\ ${ }^{2}$ Nippon Lever B.V., Hagadai, 38, Haga, Tochigi 321-33, Japan
}

Received March 12, 1997; Accepted September 6, 1997

\begin{abstract}
Lipase modification by addition of lipid is a simple and effective way to greatly improve enzyme activity for $n$-hexane based interesterification and hydrolysis reactions. The ranges of modifying lipids and lipases were evaluated, with stearic acid and lipase Saiken 100 (Rhizopus japonicus) investigated in more detail. Enzyme protein recovery and activity were influenced by the quantity of stearic acid addition and the $\mathrm{pH}$ of the aqueous preparation phase. Modified lipase protein was characterized using SDS-PAGE electrophoresis. In addition, modified lipase was immobilized within alginate beads allowing for easy biocatalyst separation and re-use for hydrolysis reactions in $n$-hexane.
\end{abstract}

Keywords: modified lipase, hydrolysis, interesterification, stearic acid, protein, fats, oils

Lipases are of great interest because of their ability to convert fats and oils into high value products (Bjorkling et al. 1991; Vulfson, 1993). Reaction water content is critical for determining reaction rates with an excess favoring hydrolytic reactions (Zaks \& Klibanov, 1988). Water content can be regulated using organic solvents (Laane et al, 1987). In addition, organic reaction media improves substrate solubility and stability and aids facile product recovery (Dordick, 1989; Klibanov, 1990). However, crude lipases typically show little or no activity in organic solvents, hence methods to improve both the activity and stability are of particular importance (Baillargeon \& Sonnet, 1988; Basri et al, 1992). One approach has been to immobilize lipase on proper powder in the presence of a polyol (Yamane et al., 1990; Dabuis \& Klibanov, 1993; Triantafyllou et al., 1995). Enzyme modification with polyethylene glycol (Baillargeon \& Sonnet, 1988; Kodera et al., 1994) or solubilization with reversed micelles (Yamada et al., 1994, Marangoni et al., 1993; Hayes \& Gulari, 1990) was also attempted.

Enzyme coating by oil soluble surfactants has also improved activity in organic media (Okahata \& Ijiro, 1988; Goto et al., 1993, 1995; Basheer et al., 1995a). It is thought that the hydrophilic heads of the lipid molecules attach to the lipase surface with the hydrophobic tails arranged on the outer side allowing the modified lipase to disperse in hydrophobic solvents (Okahata \& Ijiro, 1988; Basheer et al, 1995a). This modification locks the enzyme in a unique catalytically active confirmation (Basheer et al., 1995a).

This paper evaluates the suitability of various lipids for modifying lipase Saiken 100 and assesses the effect of lipid/ enzyme interactions on activity. Stearic acid modification is investigated in more detail demonstrating how preparation

*To whom correspondence should be addressed.

**Present address: University of Tsukuba, 1-1-1, Tennodai, Tsukuba, Ibaraki 305, Japan conditions can also affect activity. Modified lipase protein is characterized using SDS-PAGE electrophoresis. Other lipases are also investigated with crude and modified forms compared. In addition, the immobilization of stearic acid modified lipase within alginate beads is also discussed.

\section{Materials and Methods}

All chemicals were supplied by Wako Pure Chemicals, Ltd., Osaka, except for the following: Crude lipases Saiken 100 (Nagase Biochemicals, Osaka), Asahi (Asahi Chemicals Industry, Tokyo), Kurita (Kurita Water Industry, Tokyo), Lipolase (Novo Nordisk A/S, Bagsvaerd, Denmark), and Talipase (Tanabe Seiyaku Co. Ltd., Osaka). The enzymes contained $11.2,9.8,0.9,2.2$ and $5.3 \mathrm{wt} \%$ protein, respectively, as determined by the Hartree method (Hartree et al., 1972). All mono-, di-, and tri-glycerides were purchased from Sigma. Before use $n$-hexane was dried over molecular sieves $(200 \mathrm{~g}$ molecular sieves $4 \mathrm{~A} / 3 l n$-hexane) to give a water concentration of $10 \mathrm{mg} / \mathrm{l}$.

Analytical methods Interesterification and hydrolysis samples $(0.4 \mathrm{ml})$ were removed from the reaction media, filtered $(0.5 \mu \mathrm{m}$, Millipore) and analyzed by gas chromatography (Basheer et al., 1995a) and thin layer chromatography with a flame-ionization detector (Itoh \& Sugai, 1988).

Modified lipase preparation Lipase Saiken $(90 \mathrm{mg})$ was added to $30 \mathrm{ml}$ of $5 \mathrm{mmol} / \mathrm{l}$ tris (hydroxymethyl) aminomethane solution ( $\mathrm{pH} \mathrm{5)}$ and stirred (600 rpm) at room temperature. Fifty miligrams of stearic acid (or other lipid) dissolved in $0.6 \mathrm{ml}$ ethanol $\left(40^{\circ} \mathrm{C}\right)$ was added dropwise to the stirred solution. The mixture was sonicated for $15 \mathrm{~min}$ and then stirred for $12 \mathrm{~h}$ at $5^{\circ} \mathrm{C}$. The precipitate was recovered by centrifugation $(7000 \mathrm{~g}$ for $10 \mathrm{~min}$ ), dried under vacuum for 8 $\mathrm{h}$ and stored overnight over silica gel at room temperature. The modified lipase was kept at $5^{\circ} \mathrm{C}$ until used and had a water content of around $5 \mathrm{wt} \%$. 
Stearic acid modified lipase had a protein content of 7.3 wt\%, and lipase Saiken was previously shown to have 1,3positional specificity (Basheer et al., 1995a).

Protein electrophoresis Modified lipase protein was characterized by sodium dodecyl sulfate-polyacrylamide gel electrophoresis (SDS-PAGE) using the Phast System of Pharmacia Fine Chemicals (Tsuzuki et al., 1993).

Preparation of alginate beads Stearic acid modified lipase $(20 \mathrm{mg}$ ) was added to $2 \mathrm{ml}$ of $4 \%$ sodium alginate and mixed with $2 \mathrm{ml}$ distilled water ( $\mathrm{pH} 7$ ) or $5 \mathrm{mmol} / \mathrm{l}$ (hydroxymethyl) aminomethane tris solution $(\mathrm{pH} 5)$. The resulting solutions were stirred for $5 \mathrm{~min}$ and added dropwise to $20 \mathrm{ml}$ of $1 \%$ calcium chloride to produce alginate beads $2-3 \mathrm{~mm}$ in diameter. The beads were left for $45 \mathrm{~min}$, transferred to $0.8 \%$ barium chloride $(10 \mathrm{ml})$ for $10 \mathrm{~min}$ and finally washed with distilled water or tris solution, touch-dried with tissue paper and used for reaction studies.

Reaction conditions The hydrolysis reaction was between $121 \mathrm{mg}$ tripalmitin $(6 \mathrm{mmol} / \mathrm{l})$ and $10 \mathrm{ml}$ additional water $(400 \mathrm{mg} / l)$, while interesterification was carried out between $250 \mathrm{mg}$ tripalmitin $(12.4 \mathrm{mmol} / \mathrm{l})$ and $250 \mathrm{mg}$ stearic acid $(35 \mathrm{mmol} / \mathrm{l})$ with an additional water concentration of $0.5 \mathrm{ml}(20 \mathrm{mg} / l)$. The reactions were initiated by addition of $20 \mathrm{mg}$ crude or modified lipase to each flask containing $25 \mathrm{ml}$ dry $n$-hexane, substrates and additional water. The flasks were held in a water bath at $40^{\circ} \mathrm{C}$ and magnetically stirred at 600 $\mathrm{rpm}$. Interesterification activity is expressed as a specific interesterification reaction rate constant $k^{*}\left[l^{2} /(\mathrm{mol} \cdot \mathrm{g} \cdot\right.$ $\mathrm{h})]=\{$ interesterification reaction constant $k[l /(\mathrm{mol} \cdot \mathrm{h})]\} /$ \{biocatalyst concentration $E[\mathrm{~g} / l]\}$ (Basheer et al, 1995b). In Table 3, the interesterification activity is expressed as mmol $\mathrm{PPS} /(\mathrm{g}$ initial protein $\cdot \mathrm{h})$ in order to compare different types of lipase practically. Hydrolysis is expressed as mmol fatty $\mathrm{acid} /(\mathrm{g} \cdot \mathrm{h})$. The $\mathrm{g}$ protein refers to $\mathrm{g}$ modified lipase protein (Basheer et al., 1995b). The hydrolysis data given in Tables 1 and 2 were determined using the Novo Nordisk tributyrin assay (Novo Nordisk A/S, 1991; Mogi \& Nakajima, 1996).

Table 1. Effect of lipid on ML precipitate ( $\mathrm{Ppt}$ ) yield, Ppt protein content, protein recovery, interesterification and hydrolysis activities.

\begin{tabular}{lccccc}
\hline $\begin{array}{c}\text { Modifying } \\
\text { agent }\end{array}$ & $\begin{array}{c}\text { Ppt yield } \\
{[\mathrm{g} / l]}\end{array}$ & $\begin{array}{c}\text { Ppt protein } \\
\text { content } \\
{[\%]}\end{array}$ & $\begin{array}{c}\text { Protein } \\
\text { recovery } \\
{[\%]}\end{array}$ & $\begin{array}{c}\text { Interesterifica- } \\
\text { tion }\left[l^{2} /\right. \\
(\mathrm{mol} \cdot \mathrm{g} \cdot \mathrm{h})]\end{array}$ & $\begin{array}{c}\text { Hydrolysis } \\
{[\mathrm{mmol} /} \\
(\mathrm{g} \cdot \mathrm{h})]\end{array}$ \\
\hline Capric acid & 0.33 & 7.1 & 9.6 & 1.87 & 0.58 \\
Palmitic acid & 0.55 & 4.8 & 10.8 & 6.48 & 0.86 \\
Stearic acid & 1.24 & 3.0 & 15.2 & 24.5 & 2.10 \\
Behenic acid & 0.81 & 4.1 & 13.6 & 1.12 & 0.16 \\
Oleic acid & 0.89 & 4.0 & 14.7 & 2.45 & 1.03 \\
Linoleic acid & 0.59 & 3.7 & 8.9 & 1.40 & 0.52 \\
Linolenic acid & 0.40 & 4.2 & 6.8 & 0.29 & 0.30 \\
Mono-stearin & 1.35 & 2.8 & 15.4 & 18.7 & 1.05 \\
Di-stearin & 1.79 & 3.1 & 22.8 & 5.36 & 1.06 \\
Tri-stearin & 0.62 & 3.1 & 7.9 & 0.00 & 0.45 \\
Tri-stearin ${ }^{a}$ & 4.82 & 2.9 & 57.2 & 0.00 & 3.90 \\
Stearyl alcohol & 0.59 & 2.8 & 6.8 & 0.00 & 0.33 \\
Methyl stearate & 0.59 & 3.4 & 8.2 & 19.7 & 0.84 \\
\hline
\end{tabular}

${ }^{a)}$ Membrane separation; Ppt: precipitate formed after lipid addition to lipase solution. Lipids were added during modified lipase preparation. See Fig.1 for reaction conditions.

\section{Results and Discussion}

Effect of various lipids on lipase modification and activity During lipase modification, electrostatic interactions with cationic and anionic surfactants resulted in poor activity, with the latter type denaturing the protein structure and unable to form complexes due to electrostatic repulsion (Goto et al, 1993). As a result, saturated and unsaturated fatty acids, mono-, di-, and tri-stearin, stearyl alcohol and methyl stearate were evaluated for lipase Saiken modification (Table 1).

Of all the saturated fatty acids tested (capric, palmitic, stearic and behenic), the largest precipitate of $1.24 \mathrm{~g} / l$ and highest protein recovery of $15.2 \%$ was achieved using stearic acid. The corresponding interesterification and hydrolysis activities of $24.5 l^{2} /(\mathrm{mol} \cdot \mathrm{g} \cdot \mathrm{h})$ and $2.1 \mathrm{mmol} /(\mathrm{g} \cdot \mathrm{h})$ were also the highest (Table 1). Interesterification and hydrolysis activities were enhanced with saturated fatty acids up to carbon length $\mathrm{C}_{18}$; however, behenic acid $\left(\mathrm{C}_{22}\right)$ showed very poor activity (Fig. 1). With unsaturated fatty acids, activities were reduced compared to stearic acid $\left(\mathrm{C}_{18}\right)$ and with degree of unsaturation there was a concomitant decrease in activity (Fig. 2). It is not clear why there is such a variation in these results. Short chain length and unsaturation enhance the fluidity of fatty acids and their derivatives. Horiuti and Imamura (1978) found that long chain fatty acids (up to $\mathrm{C}_{16}$ ) and unsaturated fatty acids were the most effective for increasing lipase (Chromobacterium) activity.

With mono-, di- and tri-stearin lipase modification, only

Table 2. Effect of tris $(5 \mathrm{~mm})$ solution $\mathrm{pH}$ on stearic acid MOdified lipase Ppt (precipitate) yield, Ppt protein content, protein recovery Interesterification and hydrolysis activities.

\begin{tabular}{cccccc}
\hline Buffer $\mathrm{pH}$ & $\begin{array}{c}\text { Ppt yield } \\
{[\mathrm{g} / \mathrm{l}]}\end{array}$ & $\begin{array}{c}\text { Ppt protein } \\
\text { content } \\
{[\%]}\end{array}$ & $\begin{array}{c}\text { protein } \\
\text { recovery } \\
{[\%]}\end{array}$ & $\begin{array}{c}\text { Interesterifica- } \\
\text { tion }\left[l^{2} /\right. \\
(\mathrm{mol} \cdot \mathrm{g} \cdot \mathrm{h})]\end{array}$ & $\begin{array}{c}\text { Hydrolysis } \\
{[\mathrm{mmol} /} \\
(\mathrm{g} \cdot \mathrm{h})]\end{array}$ \\
\hline 5 & 0.867 & 11.9 & 13.7 & 23.3 & 2.89 \\
6 & 0.491 & 10.3 & 6.7 & 15.7 & 3.04 \\
7 & 0.364 & 7.15 & 3.5 & 11.6 & 2.27 \\
8 & 0.159 & 7.95 & 1.7 & 12.3 & 2.38 \\
\hline
\end{tabular}

Ppt: Precipitate formed after lipid addition to lipase solution.

pH: Modified lipase preparation.

Table 3. Crude and modified lipases, precipitate $(\mathrm{Ppt})$ yield, Ppt protein content, interesterification and hydrolysis activities.

\begin{tabular}{lcccc}
\hline Lipase & $\begin{array}{c}\text { Ppt yield } \\
{[\mathrm{mg}]}\end{array}$ & $\begin{array}{c}\text { Ppt protein } \\
\text { content }[\%]\end{array}$ & $\begin{array}{c}\text { Interesterification } \\
{[\mathrm{mmol} /(\mathrm{g} \cdot \mathrm{h})]}\end{array}$ & $\begin{array}{c}\text { Hydrolysis } \\
{[\mathrm{mmol} /(\mathrm{g} \cdot \mathrm{h})]}\end{array}$ \\
\hline Saiken & & & 0.00 & 0.30 \\
Saiken & $\mathbf{1 3 0}$ & $\mathbf{1 4 . 6}$ & $\mathbf{1 2 . 2}$ & $\mathbf{3 . 6 0}$ \\
Asahi & & & 0.00 & 1.3 \\
Asahi & $\mathbf{1 2 5}$ & $\mathbf{1 2 . 3}$ & $\mathbf{5 . 6}$ & $\mathbf{1 0 . 5}$ \\
Kurita & & & 44.4 & 62.2 \\
Kurita & $\mathbf{1 3 3}$ & $\mathbf{1 . 2}$ & $\mathbf{7 6 . 2}$ & $\mathbf{1 1 3}$ \\
Lipolase & & & 0.00 & 12.7 \\
Lipolase & $\mathbf{1 2 2}$ & $\mathbf{2 . 7}$ & $\mathbf{2 4 . 8}$ & $\mathbf{2 2 . 8}$ \\
Talipase & & & 0.00 & 3.2 \\
Talipase & $\mathbf{1 3 4}$ & $\mathbf{7 . 1}$ & $\mathbf{0 . 0 0}$ & $\mathbf{5 . 9}$ \\
\hline
\end{tabular}

Lipases: Saiken (Rhizopus japonicus), Asahi (Chromobacterium viscosum), Kurita (Pseudomonas), Lipolase (Aspergillus oryzae), and Talipase (Rhizopus delemar). Ppt: Precipitate after lipid addition to lipase solution. modification: $90 \mathrm{mg}$ crude lipase and $50 \mathrm{mg}$ stearic acid. 


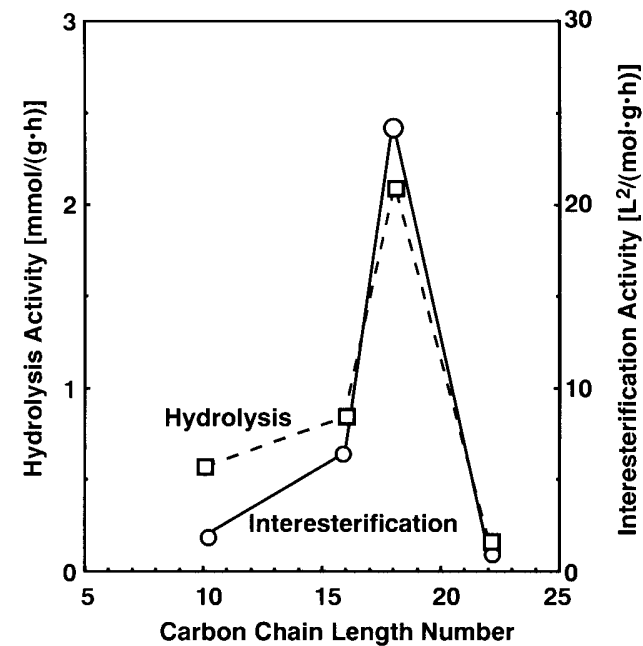

Fig. 1. Effect of fatty acid carbon chain length on modified lipase Saiken interesterification $\bigcirc$ and hydrolysis $\square$ activities. Fatty acid was added during modified lipase preparation. Interesterification reaction was between tripalmitin and stearic acid (both $250 \mathrm{mg}$ ) in $25 \mathrm{ml} n$-hexane containing $0.5 \mathrm{ml}$ (20 $\mathrm{mg} / \mathrm{l}$ ) water and $20 \mathrm{mg}$ modified lipase. Hydrolysis activity was determined by the tributyrin assay.

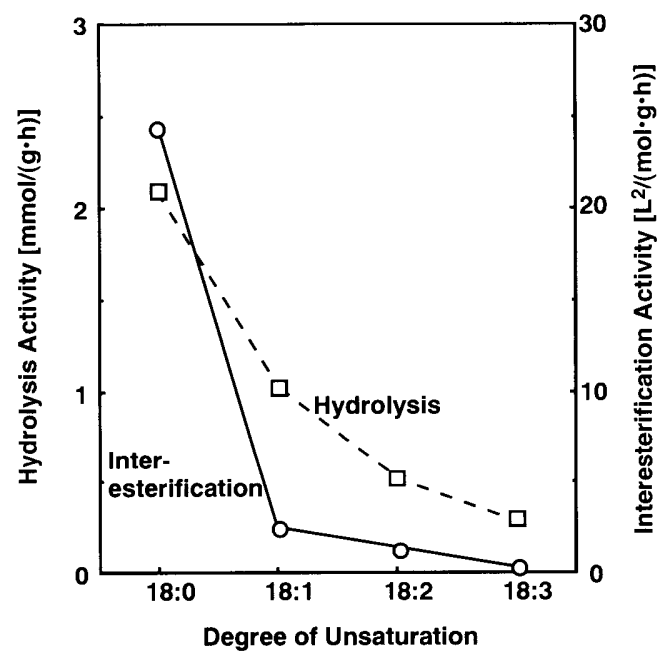

Fig. 2. Influence of degree of fatty acid unsaturation on modified lipase Saiken interesterification and hydrolysis activities. Fatty acid was added during modified lipase preparation. See Fig. 1 for reaction conditions.

mono-stearin resulted in good interesterification and hydrolysis activity (Table 1). Tri-stearin addition resulted in a stable emulsion, hence an ultrafiltration membrane was used to concentrate the modified protein from the aqueous phase. As a result, a high percentage $(57 \%)$ of protein was recovered (Table 1). Despite the vast difference between protein recovered by centrifugation $(7.9 \%)$ or membrane separation $(57 \%)$, no interesterification activity resulted in either case; however, hydrolysis activity was greatly improved with membrane separation (Table 1). Stearic acid, mono-stearin and methyl stearate-modified lipases displayed the highest activities (Table 1), while long chain primary alcohols such as stearyl alcohol showed no activity. This implies that the presence of a stearic acid group in each molecule has an important influence on activity. From these results, stearic acid was selected for all subsequent enzyme modifications having good overall activity (interesterification and hydrolysis). Interesterification was also monitored using tripalmitin and oleic acid as substrates. In this experiment, stearic acid also proved to be the best fatty acid for lipase modification activity (results not shown).

It is estimated that $170-200$ lipid molecules are required to coat the surface of a lipase molecule as a monolayer (Okahata \& Ijiro, 1988; Goto et al., 1993). The surface of a lipase molecule is slightly negatively charged with non ionic surfactant hydrogen binding probably having the most beneficial effect on enzyme activity (Okahata \& Ijiro, 1988). Mogi and Nakajima (1996) found that the hydrophilelipophile balance (HLB) value which describes the ratio of hydrophilic radicals in a surfactant was of some influence in determining activity and yield. Surfactants with HLB values below four were not useful for modifying lipases. Goto et al. (1993) suggested that surfactants with large amounts of hydrophobic groups were better due to their enhanced solubility in organic solvents with the presence of branching or a double bond showing higher activity than those without. In addition to improved solvent dispersibility, enzyme modification may also help to retain water and allow for conformational flexibility (Green \& Nakajima, 1995; Zaks \& Klibanov, 1988).

Stearic acid modification of lipase Saiken: preparation conditions Stearic acid used to modify lipase Saiken was initiated by the dropwise addition of stearic acid (ethanol) to a stirred lipase solution. The weight ratio of stearic acid addition to lipase ( $R$ value) was investigated with the enzyme weight kept constant $(90 \mathrm{mg})$. Increasing the $R$ value from 0 to 1 produced a linear response in the amount of modified precipitate recovered (Fig. 3). The percentage of lipase protein in the precipitate peaked at an $R$ value of 0.55 after which the percentage decreased (not shown). The protein recovered reached a maximum (ca. 20\%) with an $R$ value of 0.55 with no further increase thereafter (Fig. 3). As expected, the mmol free fatty acid (FFA)/g modified ppt after 24-h hydrolysis reaction mirrored the precipitate protein content with the highest activity between $R$ values 0.2 and 0.6 (Fig. 3). An $R$ value of 0.55 was subsequently selected for future experiments because it produced a high precipitate yield with the highest protein content and good hydrolysis activity. It also represented the point after which no more lipase was recovered by further addition of stearic acid.

Lipase Saiken was modified using stearic acid (as previously described) with $25 \%$ of the lipase protein recovered. The supernatant was decanted and $50 \mathrm{mg}$ of stearic acid was added to it resulting in a further $16 \%$ of protein recovered. Two further stearic acid additions $(50 \mathrm{mg})$ to the decanted supernatants recovered a further 9 and $8 \%$ respectively. In total therefore, $58 \%(5.8 \mathrm{mg})$ of the initial protein $(10.1 \mathrm{mg})$ was recovered by a four-step addition of stearic acid. This far exceeds the $25 \%$ or so that was recoverable even at very high $R$ values after one-step addition. The presence of the modified lipase may alter the HLB producing unfavorable binding dynamics for any further interaction. Only when the modified protein is removed (centrifugation) and the balance shifted 


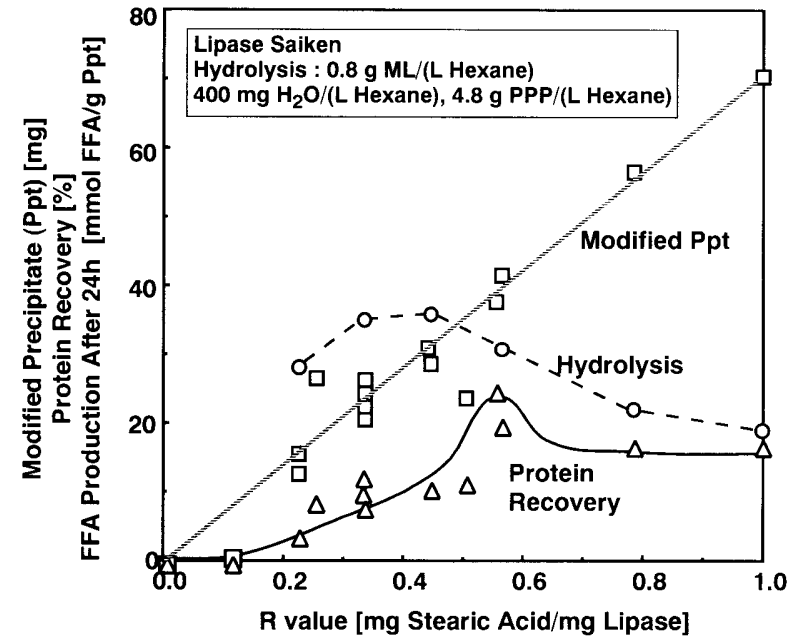

Fig. 3. The effect of the stearic acid:lipase Saiken weight ratio ( $R$ value) on modified precipitate yield $\Pi(\mathrm{mg})$, protein recovery $\triangle(\%)$ and free fatty acid (FFA) production after $24 \mathrm{~h}$ hydrolysis reaction in $n$-hexane. Stearic acid was added during modified lipase preparation. Hydrolysis reaction conditions: $20 \mathrm{mg}$ modified enzyme, $25 \mathrm{ml} n$-hexane, $10 \mathrm{ml}$ water, $121 \mathrm{mg}$ tripalmitin.

does any further modification proceed (Mogi \& Nakajima, 1996).

Protein recovery after stearic acid modification was also affected by the $\mathrm{pH}$ of the aqueous preparation phase with $\mathrm{pH}$ 5 proving to be the optimal value. Values above $\mathrm{pH} 5$ produced a decrease in the amount of modified lipase precipitate recovered and activity (Table 2 ). A tris solution (5 $\mathrm{mmol} / \mathrm{l}$ ) was also found to be more effective than distilled water $(\mathrm{pH} 7)$ for protein recovery over a range of $\mathrm{pH}$ values (Basheer et al. 1995a). This indicates that ionic interactions between stearic acid and lipase are important. As a result, lipase was dissolved in tris solution $(\mathrm{pH} \mathrm{5)}$ prior to modification.

Effect of modification on crude lipases Six lipases were selected and their crude and modified forms compared. Modification was undertaken as previously described with stearic acid. Both interesterification and hydrolysis activities were monitored. In all cases, the interesterification activity of the crude enzymes were zero or very low. Modification resulted in a dramatic increase in interesterification activity (Table 3). Of the lipases tested, modified Saiken, Asahi, Kurita and Lipolase showed the best interesterification activities. In contrast, modification did not result in enhanced hydrolysis activity for all enzymes with only Saiken, Asahi and Kurita preparations having improved performance. Overall, the modified enzymes Asahi and Kurita were best for interesterification and hydrolysis respectively. However, the high cost of Asahi and availability of Kurita may prohibit commercial use. In addition, the proportion of hydrolytic diglyceride byproducts produced during interesterification is also important. It may be beneficial therefore to select a particular lipase for interesterification or hydrolysis or to mix two lipases exhibiting these different properties; indeed it may also be beneficial to mix on the basis of activity and cost.

$S D S-P A G E$ Modified lipase protein was characterized using SDS-PAGE electrophoresis (Fig. 4). Sample 1 is crude lipase Saiken which contained a range of proteins with differing molecular weights. Sample 4 shows the molecular weights of standard proteins. Stearic acid modification (samples 2 and 3) caused a selective separation of lipase protein corresponding to a molecular weight of around 30,000. As previously mentioned, crude lipase has little activity in $n$-hexane. This selective adsorption of "active" protein after stearic acid modification may also help to explain why modified lipases are much more active than their crude counterparts.

Immobilization within alginate beads Inherent problems of biocatalyst recovery and separation from the products and modifying lipid led us to explore the possibility of immobilizing modified lipase within alginate beads $(2-3 \mathrm{~mm}$ diameter). Sodium alginate (4\%) was chosen as it involves immobilization under mild conditions (temperature, $\mathrm{pH}$ ).

Initial experiments showed there was a slight downfall in the hydrolysis activity over consecutive 12 -h batch reactions using immobilized modified lipase (IML) as opposed to modified lipase (ML). However, this decrease was not so significant, especially if the activity period with the IML can be extended. Another experiment was conducted to investigate the effect of alginate preparation (aqueous phase inside the beads) and bead "re-conditioning" on hydrolysis activity over consecutive batch reactions using $5 \mathrm{mmol} / l$ tris solution $(\mathrm{pH} \mathrm{5)}$ and distilled water $(\mathrm{pH} 7)$.

Alginate beads prepared in water (A and B; Fig. 5) showed very poor activity (dark shade) when compared to beads prepared with tris solution (C and D). Furthermore, after reconditioning (beads suspended in water or tris solution for $1 \mathrm{~h}$; light shade), those beads suspended in solution (B and D) retained a high percentage of their activity after a further 12-h reaction period compared to those re-conditioned in water $(\mathrm{A}$ and $\mathrm{C}$ ). In the case of $\mathrm{D}$ where the beads were prepared and

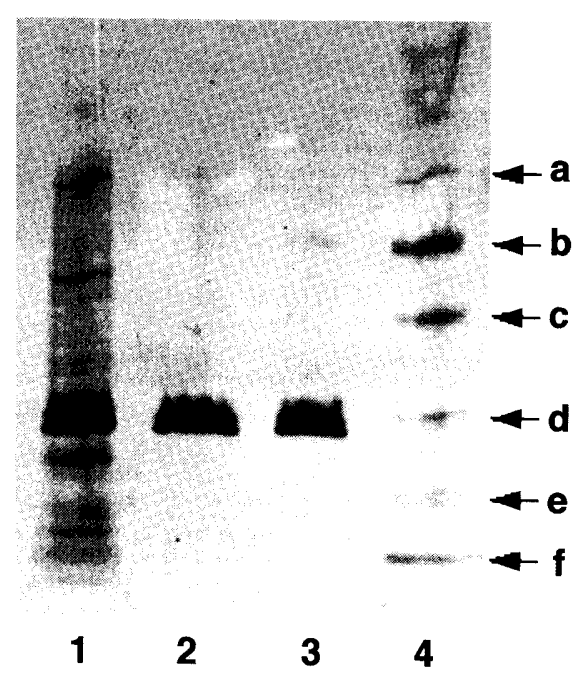

Fig. 4. SDS-PAGE electrophoresis. Sample $\mathrm{l}$ is crude lipase Saiken standard ( $30 \mathrm{mg} / \mathrm{ml}$ water). Samples 2 and 3 are stearic acid modified precipitates (10 and $11 \mathrm{mg}$ modified lipase $/ \mathrm{ml}$ water respectively). Sample 4 is molecular weight standards: a, phosphorylase b (M.W. 94,000); b, albumin (M.W. 67,000); c, ovalbumin (M.W. 43,000); d, carbonic anhydrase (M.W. 30,000); e, trypsin inhibitor (M.W. 20,100); f, $\alpha$-lactalbumin (M.W 14,400). 


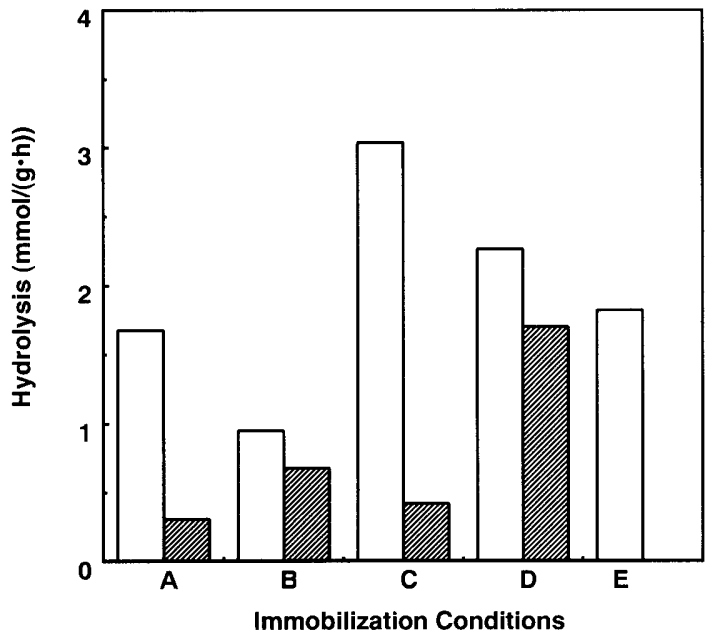

Fig. 5. Immobilization of modified lipase within alginate beads. Effect of water and tris solution during bead preparation and re-conditioning on free fatty acid production during hydrolysis in $n$-hexane. Consecutive batch reactions (first $\square$, second $\mathrm{m}$ ) of $12 \mathrm{~h}$ were undertaken. Immobilized beads ( $2-3$ $\mathrm{mm}$ diameter) contained $20 \mathrm{mg}$ modified lipase. The reaction medium contained $25 \mathrm{ml} n$-hexane, $10 \mathrm{ml}(400 \mathrm{mg} / \mathrm{l})$ water and $121 \mathrm{mg}$ tripalmitin.

Bead preparation $(25 \mathrm{ml})$

Re-conditioning (25 ml)

A- water (distilled, $\mathrm{pH} 7$ )

B- water

C- tris solution

water

D- tris solution

tris solution $(5 \mathrm{mmol} / l, \mathrm{pH} 5)$

water

tris solution

E- not immobilized (standard modified preparation)

re-conditioned in tris solution, $80 \%$ and $75 \%$ of the initial diglycerides (not shown) and free fatty acid $(\mathrm{mmol} / \mathrm{l}$ ) were retained after a further reaction period $(12 \mathrm{~h})$ in fresh medium (Fig. 5). If preparation D is compared to control $\mathrm{E}$ (modified lipase), then a slight shortfall appears hydrolysis activity using alginate beads. Tris solution ( $\mathrm{pH} 5$ ) has a significant effect on retaining modified enzyme activity within alginate beads

Immobilization of modified lipase within alginate beads allows for easy biocatalyst re-use and separation. Alginate beads are mechanically rigid and confer stability in organic solvents. However, disadvantages include longer reaction times due to poor mass transfer rates, difficult large scale preparation and bead shrinkage due to water stripping by the solvent. In addition, it is extremely difficult to control the reaction water content. Preparation of "dry" immobilized modified lipase catalysts suitable for interesterification reactions is currently underway.

Acknowledgments The first author had a research fellowship from the Science and Technology Agency of the Japanese government. The authors also thank K. Fujiwara, Nippon Lever B.V., Japan for his helpful advice. This work was partly supported by Bio-Renaissance of the Ministry of Agriculture, Forestry and Fisheries (BRP97-I-A-6).

\section{References}

Baillargeon, M.W. and Sonnet, P.E. (1988). Polyethylene glyco modification of Candida rugosa lipase. JAOCS, 65, 1812-1815.

Basheer, S., Mogi, K. and Nakajima, M. (1995a). Surfactant-coated lipase for the catalysis of the interesterification of triglycerides and fatty acids. Biotechnol. Bioeng., 45, 187-195.

Basheer, S., Mogi, K. and Nakajima, M. (1995b). Interesterification kinetics of triglycerides and fatty acids with modified lipase in $n$-hexane. JAOCS, 72, 511-518.

Basri, M., Ampon, K., Yunus, W.M.Z., Razak, C.N.A. and Salleh, A.B. (1992). Amidination of lipase with hydrophobic imidoesters. JAOCS, 69, 579-583.

Bjorkling, F., Godtfredsen, S.E. and Kirk, O. (1991). The future impact of industrial lipases. TIBTECH, 9, 360-363

Dabulis, K. and Klibanov, M. (1993). Dramatic enhancement of enzymatic activity in organic solvents by lyoprotectants. Biotechnol. Bioeng., 41, 566-571.

Dordick, J.S. (1989). Enzymatic catalysis in monophasic organic solvents. Enzyme Microb. Technol., 11, 194-211.

Goto, M., Kameyama, H., Goto, M., Miyata, M. and Nakashio, F. (1993). Design of surfactants suitable for surfactant-coated enzymes as catalysts in organic media. J. Chem. Eng. Jpn., 26, 109-111.

Goto, M., Goto, M., Kamiya, N. and Nakashio, F. (1995). Enzymatic interesterification of triglyceride with surfactant-coated lipase in organic media. Biotechnol. Bioeng., 45, 27-32.

Green, K.D. and Nakajima, M. (1995). Immobilized modified lipase for interesterification and hydrolysis reactions in hexane. $A d v$. Biosep. Eng., 53, 91-94.

Hartree, E.F. (1972). Determination of protein: A modification of the Lowry method that gives a linear photometric response. Anal. Biochem., 48, 422-427.

Hayes, D.G. and Gulari, E. (1990). Esterification reactions of lipase in reverse micelles. Biotechnol. Bioeng., 35, 793-801.

Horiuti, Y. and Imamura, S. (1978). Stimulation of Chromobacterium Lipase activity and prevention of its adsorption to palmitoyl cellulose by hydrophobic binding of fatty acids. J. Biochem., $\mathbf{8 3}$, 1381-1385.

Itoh, T. and Sugai, A. (1988). Application of thin layer chromatography flame ionization detection system for lipid analysis. Proceedings of Session Lectures and Scientific Presentations on ISF-JOCS World Congress, vol. II, paper 7Ll, pp. 833-841.

Klibanov, A.M. (1990). Asymmetric transformations catalyzed by enzymes in organic solvents. Acc. Chem. Res., 23, 114-120.

Kodera, Y., Nishimura, H., Matsushima, A., Hiroto, M. and Inada, Y. (1994). Lipase made active in hydrophobic media by coupling with polyethylene glycol. JAOCS, 71, 335-338.

Laane, C., Boeren, S., Vos, K. and Veeger, C. (1987). Rules for optimization of biocatalysts in organic solvents. Biotechnol. Bioeng., 30, 81-87.

Marangoni, A.G., McCurdy, R.D. and Brown, E.D. (1993). Enzymatic interesterification of triolein with tripalmitin in canola lecithinhexane reverse micelles. JAOCS, 70, 737-744.

Mogi, K. and Nakajima, M. (1996). Selection of surfactant-modified lipases for interesterification of triglyceride and fatty acid. JAOCS, 73, $1505-1512$.

Novo Nordisk A/S (1991). Analytical method, AF 95/6-GB.

Okahata, Y. and Ijiro, K. (1988). A lipid-coated lipase as a new catalyst for triglyceride synthesis in organic solvents. J. Chem. Soc. Chem. Commun., 1392-1394.

Triantafyllou, A.Ö., Wehtje, E., Adlercreutz, P. and Mattiason, B. (1995). Effects of sorbitol addition on the action of free and immobilized hydrolytic enzymes in organic media. Biotechnol. Bioeng., 45, 406-414.

Tsuzuki, W., Kasumimoto, H., and Kobayashi S. (1993). Use of a synthetic detergent to partition mixtures. Analyst, 118, 131-135.

Vulfson, E.N. (1993). Enzymatic synthesis of food ingredients in low-water media. Trends Food Sci Technol., 4, 209-215.

Yamada, Y., Kuboi, R. and Komasawa, I. (1994). Extraction of enzymes and their activities in AOT reverse micellar systems with nonionic surfactants. J. Chem. Eng. Jpn., 27, 404-409.

Yamane, T., Ichiryu, T., Nagata, M., Ueno, A. and Shimizu, S. (1990) Intramolecular esterification by lipase powder in microaqueous benzene: Factors affecting activity of pure enzyme. Biotechnol. Bioeng., 36, 1063-1069.

Zaks, A. and Klibanov, A.M. (1988). The effect of water on enzyme action in organic media. J. Biol. Chem., 263, 8017-8021. 